\title{
DISCURSO DO PROFEESOR ARY FLORENCIO GUIMARÃES
}

“E-me grato falar nesta oportunidade, em que o Egrégio Conselho Universitário, pela voz do Magnífico Reitor Theodócio Jorge Atherino, faz a entrega solene do título de "Professor Emérito" ao Dr. Oscar Martins Gomes.

Varias razões justificam o meu contentamento pessoal. Admirador e leitor do homenageado, posteriormente seu colega da antiga Faculdade de Direito, na categoria de catedrático, posto a que ascendemos por concurso de títulos e provas, seu amigo e companheiro de todas as horas, tais laços de amizade e coleguismo bastariam, por certo, para dar às minhas palavras, neste momento, caráter de emoção e sincera alegria.

Mas, meus senhores, não se trata, aqui, evidentemente, de u'a simples e fraterna reunião de antigos colegas e amigos, ligados às melhores tradições de nossa querida Faculdade de Direito, da Universidade do Paraná.

Outro sentido, de profundo significado transpessoal, é a razão de ser desta solenidade.

É que, jubilado há alguns anos pelo atingimento da idade limite prevista constitucionalmente, o eminente professor, o notável advogado e o festejado poeta Oscar Martins Gomes e, sobretudo, essa figura humana, tranqüila e admirável, bemquista e benfazeja, aqui está justamente para receber a láurea suprema, que the foi outorgada pelo Conselho Universitário.

$\mathrm{Na}$ personalidade polivalente de Oscar Martins Gomes, sem dúvida, vamos encontrar uma vida repleta de serviços às nossas gerações jurídicas, através de sua cátedra, de seus livros, de suas teses e dos incontáveis e brilhantes trabalhos de sua lavra e que opu- 
lentaram nossa bibliografia especializada no campo do Direito Internacional Privado. Para exaltar tais predicados, no campo da ciência de Ulpiano, basta referir as teses e proposições que apresentou e defendeu com brilho em congressos nacionais e internacionais, todas reveladoras de cultura invejável e alto merecimento, no fundo e na forma, afora uma larga e fecunda produção jurídica, a miude publicada nas principais revistas do País. Sobreleva, nessa laboriosa contribuição às nossas letras jurídicas, o importante livro" Leis e Normas de Direito Internacional Privado", com que a conhecida e prestigiosa editora Saraiva, de São Paulo, enriqueceu, no ano de 1956, a sua coleção e que, no dizer do saudoso e eminente professor e desembargador Manoel Lacerda Pinto, veio preencher verdadeira lacuna entre nós, "manual como este que o autor, com sua paciência, tão minha conhecida, de pesquisador tenaz e minucioso e com o talento comprovado e a cultura invejável, que o levaram à cátedra da bela e árdua disciplina, realizou com brilho. Já a rebusca de leis atinentes à matéria era tarefa suficiente a fazer desanimar alguém que não tivesse a sua têmpera. E mais as duzentas notas elucidadoras do texto, tudo constitui contribuição inestimável para solução de obstáculos com que se defrontam os estudiosos".

Mas ao jurista Oscar Martins Gomes, como certa feita salientou Andrade Murici, em crônica inserta na Revista "O Cruzeiro", do Rio de Janeiro, "nada de artístico the tem sido alheio". E Andrade Murici exalta, escudado na sua indesmentida autoridade, o poeta e o literato, autor de Goiobang, livro alusivo às origens e à formação do Estado e dado a lume em 1953, a propósito do centenário do Paraná, e como contribuição do autor ao II Congresso Brasileiro de Folciore, naquele ano reunido em Curitiba, não regateando elogios ao poema épico, "seqüência de quadros sumamente evocativos, vários dos quais antológicos", no dizer do renomado autor do "Panorama do Movimento Simbolista Brasileiro". Nessa obra admirável, verdadeira síntese histórica e etnográfica, com poemas de autêntica poesia, aurida nas mais belas e suaves fontes locais, vemos e sentimos, como sublinhou Nelson Luz, a nossa.

"Curitiba cantada com emoção, num rítmo admirável. Um descritivo construido, essencial, decisivo e, o que é importante, espontâneo. Há ainda a precisão histórica. E, como cúpula, poesia".

As virtudes espirituais e inteletuais do Professor Oscar Martins Gomes, nessa obra amplamente louvada pela crítica de todo o País, foram elogiadas, com mão de mestre, em síntese lapidar, pelo sociólogo Faris Michaele: 
"É a voz do Paraná eterno que aí se faz ouvir, em versos de inigualável maviosidade, força expressiva e talento de inesgotável inspiração. Que Deus abençoe as mãos que esculpiram o monumento poético do nosso centenário".

Tudo isso revela, meus senhores e minhas senhoras, a grandeza moral e espiritual do nosso homenageado, cuja produção no campo da literatura, não só em prosa, como em versos, dentre tantos outros exemplos dignos de nota, está a mostrar, na atualidade e também aos pósteros, no mundo conturbado que vivemos, não raro eclipsado pelos rasgos transeuntes de um mercantilismo vão ou de abjeto materialismo, que "não fazem mal as musas aos doutores.

Vulto Benemérito de Curitiba e Cidadão Benemérito do Paraná, conforme deliberação de nossas assembléias representativas; partícipe de todos os movimentos culturais e literários que empolgaram o nosso Estado; antes e depois da década de 1930; político sereno e equitativo; presidente dos sodalícios culturais do Paraná, como o Instituto dos Advogados, Academia Paranaense de Letras, Centro Cultural Ítalo-Brasileiro Dante Alighieri e tantos outros organismos de cultura, música e belas artes; advogado militante e professor catedrático da antiga Faculdade de Direito, com participação ativa em vários prélios de inteligência verificados em concursos na Universidade do Paraná e em outras Universidades brasileiras - o Professor Oscar Martins Gomes constitui, sem dúvida, um exemplo marcante do quanto podem o talento, o trabalho construtivo e o amor às mais alcandoradas manifestações do espírito e do coração.

Foi agraciado, por isso mesmo, com o título de Cidadão Honorário do antigo Estado da Guanabara, a cujo patrimônio folclórico também acrescentou páginas de admirável beleza poética e intensa vibração popular.

Hoje, no dia que relembra a fundação de Curitiba, aqui nos reunimos para a festa que significa, par droit de conquête, o coroamento feliz e sobretudo justiceiro de uma vida profícua e verdadeiramente dedicada ao bem-comum. Festa simples, porém expressiva, que se registra, nos fastos de nossa tradicional Universidade, como uma clarinada de pura eticidade, de cumprimento fiel e cavalheiresco dos nobres e árduos deveres docentes e de um entranhado amor ao Direito.

Daí o nosso júbilo insopitado; daí a nossa presença nesta solenidade, para significarmos, antes e acima de tudo, os nossos efusivos cumprimentos ao antigo e caríssimo colega de tantos trabalhos e esforços em favor da mocidade estudiosa pela justa e merecida 
honraria de que ora se faz alvo por decisão unânime do egrégio Conselho Universitário.

Ao Professor Emérito Doutor Oscar Martins Gomes, a saudação carinhosa e coracionalmente agradecida da antiga Faculdade de Direito, da Universidade Federal do Paraná". 